\title{
Injury to Spleen with Open Wound into Cavity
}

National Cancer Institute

\section{Source}

National Cancer Institute. Injury to Spleen with Open Wound into Cavity. NCI Thesaurus. Code C35244.

Trauma to the spleen associated with a break in the tissue that extends into the abdominal cavity. 